\title{
Non-exposure parenting increases risk of bullying behavior in junior high school students
}

\author{
Surilena* and Jessica**
}

\begin{abstract}
*Department of Psychiatry, Faculty of Medicine, Atma Jaya Catholic University **Medical Profession Program, Faculty of Medicine,

Atma Jaya Catholic University of Indonesia

\section{BACKGROUND}

Bullying behavior is one of many behavioral and disciplinary problems among school students, which has a wide impact on youth, families, schools, and communities. Parenting and the role of parents as good educators (exposure) can prevent mental, emotional and behavioral disorders caused by bullying. The aim of this study was to determine the role of self-esteem and family factors on bullying behavior in junior high schools students.
\end{abstract}

Correspondence :

Dr. dr. Surilena, $\operatorname{SpKJ}(\mathrm{K})$

Department of Psychiatry,

Faculty of Medicine,

Atma Jaya Catholic University of Indonesia,

Jl. Pluit Raya No. 2, North Jakarta, Indonesia

Phone: +6221-6693168

Fax: +6221-6606123

Email: surilenahasan@yahoo.co.id / surilena@atmajaya.ac.id

Univ Med 2016;35:56-64

DOI: 10.18051/UnivMed.2016.v35.56-64 pISSN: 1907-3062 / eISSN: 2407-2230

This open access article is distributed under a Creative Commons Attribution-Non Commercial-Share Alike 4.0 International License

\section{METHODS}

A cross-sectional study was conducted including 1324 junior high school students of Penjaringan village, North Jakarta. Respondents filled out questionnaires on demographics (age, gender, economic status, educational level), Rosenberg self-esteem questionnaire, strength and difficulties questionnaire, Olweus bullying questionnaire, Hamilton scale for depression, parenting style, and family adaptability and cohesion scales III. Simple and multivariate logistic regression tests were used to analyze the data.

\section{RESULTS}

Respondents consisted of $53.5 \%$ females and $46.5 \%$ males, with an age range of 13-16 years. A total of 45\% was involved in bullying (victims, perpetrators, and victims and perpetrators). Gender, self-esteem, family relationships, and parenting were significantly associated with bullying role ( $\mathrm{p}<0.05)$. Multiple logistic regression analysis showed that self-esteem (odds ratio $=23.89 ; 95 \%$ CI:7.899-12.990) and non-exposure parenting (odds ratio $=39.11 ; 95 \%$ CI:2.455-8.210) were significantly associated with bullying behavior.

\section{CONCLUSIONS}

Non-exposure parenting was the most relevant risk factor of bullying behavior. Low self-esteem increases the risk of bullying behavior. These findings suggest the need of timely bullying prevention and intervention programs that should have a special focus on families of primary high school students.

Keywords: Bullying behavior, family factors, self-esteem, junior high school students 


\section{INTRODUCTION}

Bullying is a phenomenon that is widespread in the whole world. Bullying is a term that sounds foreign to most Indonesians, although this phenomenon has been occurring for a long time and in various aspects of life, including the educational world. ${ }^{(1)}$ Bullying is a phenomenon characterized by negative acts towards peers, with the intention to hurt, that is performed repeatedly and is accompanied by physical or verbal aggression, or relational harassment by social manipulation and ugly rumors. During the last decades alarming conditions have been found, where more bullying is performed by adolescents, particularly in schools. ${ }^{(2)}$ The considerable number of cases of violence that occur at present among school children is of much concern to educators and parents. ${ }^{(2,3)}$ The school that should be a place for the children to acquire knowledge and to help persons in forming a positive character, turns out to be a place for the fertile growth of bullying practices, thus inspiring fear to children and adolescents. ${ }^{(2,3)}$

The prevalence of bullying is estimated to be up to $50 \%$ in several countries in Asia, the US and Europe. In the Phillippines the prevalence is as large as $21.2 \%$ and in Thailand as large as $10.3 \%$ in children aged $11-16$ years. ${ }^{(4)}$ The prevalence of bullying in junior high school students varies between countries, being $11 \%$ in the US, $14.7 \%$ in Italy and $27 \%$ in the UK. ${ }^{(5,6)} \mathrm{A}$ survey in China states that $20 \%$ of adolescents experience bullying behavior, while in Venezuela around $31.5 \%$ of adolescents experience bullying behavior. ${ }^{(4)}$ The prevalence of bullying in state primary school pupils is $89.5 \% .^{(7)}$ Accurate data on the prevalence of bullying in junior high school students in Indonesia are lacking.

Bullying is behavior that is deleterious to the development of mental and physical health of children or adolescents. Bullying behavior should not be tolerated, since it has serious physical, psychological, and psychosomatic effects for all concerned, i.e. the perpetrators (bullies), victims, and bully-victims (aggressive victims, persons who are both victims and bullies), that can persist into adult life. Some of the effects that may occur are difficulties in socializing, self-withdrawal, anxiety, depression, suicidal ideation [thinking about or attempting suicide], eating problems, somatic symptoms (decreased appetite, headaches, sleeping problems, abdominal pain, and easy fatiguability, substance abuse, and other mental disturbances. ${ }^{(8,9)}$ Van der Wal et al. ${ }^{(10)}$ state that with regard to bullying in schools, particularly those who are involved as victim or bully-victim, may feel excluced, have decreased academic achievement, become drop-outs, and be lacking in self-esteem. The factors affecting the occurrence of bullying behavior, particularly in schools, are internal and external. Internal factors are age, gender, physical condition, psychological condition, and others. ${ }^{(11)}$

The phenomenon of bullying behavior is like an iceberg that is apparently "small" at the surface, but may have many problems in store that are mostly not easy to discover or to be aware of, by teachers or even parents. ${ }^{(1,2)}$ The community (especially parents and teachers) are frequently misled by the apparent "insignificance" of bullying behavior, so that they ignore the future impact and extraordinary danger towards both victims and bullies, as well as bully-victims, and the widespread impact towards the community. ${ }^{(1,3)}$ There is a need to detect at an early stage the presence of bullying behavior and to know the role of family factors, so as to be able to take early preventive measures against bullying behavior, particularly in schools, and to perform at an early stage interventions on the resulting effects, in their physical as well as mental aspects. Therefore this study aimed to determine the role of family factors and self-esteem in bullying behavior among junior high school students.

\section{METHODS}

\section{Study design}

The design of the study used was crosssectional and the study was conducted from April - September 2015 at a junior high school in the 
kelurahan (village) of Penjaringan, North Jakarta.

\section{Study subjects}

There were 1336 students of state and private junior high schools in Kelurahan Penjaringan, North Jakarta. The study sample was recruited by consecutive sampling. All male and female students of the I, II, and III grades of state and private junior high schools in Kelurahan Penjaringan, North Jakarta, were selected as study subjects.

\section{Instruments}

The instruments used in this study were as follows. First, the demographic questionnaire comprising age, gender, educational level, and economic status of the family. Second, the Rosenberg self-esteem questionnaire comprising 10 questions with 4 categories. Self-esteem is high if the total score is $\geq 15$, while self-esteem is low if the total score is $<15$. Third, the strength and difficulties questionnaire (SDQ) comprising 28 questions used to measure behavioral and emotional problems; behavioral problems are positive if the total score is $\leq 15$ and negative if the total score is $\geq 16$. Fourth, the Olweus bullying questionnaire (OBQ) comprising 39 questions and consisting of 2 parts, i.e. a questionnaire about victims of bullying (questions nos. 1-23) and a questionnaire about perpetrators of bullying (questions nos. 24-39); bullying behavior is positive if the respondent selects option c (only 2 or 3 times per month), or d (around once weekly), or e (more than once weekly) and bullying behavior is negative if the respondent selects option a (I did not do that in the last 6 months), or b (once or twice in the last 6 months). Fifth, the Hamilton rating scale for depresssion (HDRS) comprising 17 questions used to measure depression. The interpretation of the total score is: $0-7=$ no depression, $8-13=$ mild depression, 14-18= moderate depression, $19-22=$ severe depression, and $\geq 23=$ very severe depression. Next, the questionnaire on parental nurturing pattern (parenting type) consisting of
26 questions in group A and 6 questions in group $\mathrm{B}$. The parenting pattern involves non-exposure if the total score is $\leq 27$ and exposure if the total score is $\geq 28$. Finally, the questionnaire on family relations (family adaptibility and cohesion scales III) consisting of 16 questions with their interpretations. There are 4 types of family cohesion and 4 types of family adaptibility, which are subsequently summarized into 3 types of family relation, i.e. balanced (high), midrange and extreme (low) family relation.

\section{Statistical analysis}

The data of this study were analyzed using binary logistic regression analysis for an association of bullying behavior with self-esteem, gender, type of family relation, and parenting pattern. Multiple logictic regression analysis was used for finding an association of bullying behavior with self-esteem and parenting pattern.

\section{Ethical clearance}

This study obtained ethical clearance from the Ethics Commission of the Faculty of Medicine, Atma Jaya Catholic University of Indonesia in March 2015.

\section{RESULTS}

There were 12 subjects who were not present during the course of the study, so that they were excluded. The participating subjects comprised 1324 persons, among whom $53.5 \%$ females, $46.5 \%$ males, with an age range of 1316 years, while $91.3 \%$ subjects had a middle economic status. At junior high schools, the subjects were mostly in grade I (35.9\%), grade II $(32.8 \%)$ and grade III (31.3\%). This study also showed that $45.1 \%$ of the subjects were involved in bullying behavior, i.e. as victims (18.6\%), bullies (13.4\%) and bully-victims $(13.1 \%)$. In contrast, the proportion of subjects who were not involved in bullying behavior was $54.9 \%$. The types of bullying behavior that were encountered were verbal bullying (37.6\%), psychological and emotional bullying (29.9\%), 
Table 1. Distribution of characteristics and bullying behavior of study subjects $(n=1324)$

\begin{tabular}{|c|c|}
\hline Characteristic of responde nt & $n(\%)$ \\
\hline \multicolumn{2}{|l|}{ Age (years) } \\
\hline 13 & $455(33.4)$ \\
\hline 14 & $425(32.1)$ \\
\hline 15 & $400(30.2)$ \\
\hline 16 & $44(3.3)$ \\
\hline \multicolumn{2}{|l|}{ Gender } \\
\hline Males & $615(46.5)$ \\
\hline Fernales & $709(53.5)$ \\
\hline \multicolumn{2}{|l|}{ Family socio-economic status } \\
\hline Midall e (Income $\leq$ Rp. 2.500 .000$)$ & $1209(91.3)$ \\
\hline Low (Income $>$ Rp.2.500.000) & $115(8.7)$ \\
\hline \multicolumn{2}{|l|}{ Echucation } \\
\hline Grade I junior high sohool & $475(35.9)$ \\
\hline $\begin{array}{l}\text { Grade II juri or high schod } \\
\text { Grade III junior high school }\end{array}$ & $\begin{array}{l}434(32.8) \\
415(31.3)\end{array}$ \\
\hline \multicolumn{2}{|l|}{ Bullying behavior } \\
\hline Victim & $246(18.6)$ \\
\hline Bully & $177(13.4)$ \\
\hline Bully-victim & $173(13.1)$ \\
\hline Bystander/not invol ved & $728(54.9)$ \\
\hline \multicolumn{2}{|l|}{$\begin{array}{l}\text { Type of bullying behavior } \\
\text { (victims, bullies, bully- vi ctims, }\end{array}$} \\
\hline $\mathrm{n}=596)$ & $147(24.7)$ \\
\hline Physical & $224(37.6)$ \\
\hline Verbal & $178(29.9)$ \\
\hline $\begin{array}{l}\text { Psychological and em dional } \\
\text { Cyber bullying }\end{array}$ & $47(7.8)$ \\
\hline \multicolumn{2}{|l|}{ Victins \& Bully-Victims } \\
\hline \multicolumn{2}{|l|}{ Perpetrat of of bullying } \\
\hline Classmate & $192(58.5)$ \\
\hline Class senior & $105(32.1)$ \\
\hline Classjunior & $31(9.4)$ \\
\hline \multicolumn{2}{|l|}{ Location of bullying behavi $\alpha$} \\
\hline Classoom & $133(37.2)$ \\
\hline Hallway & $78(21.8)$ \\
\hline Playgrounds & $55(15.3)$ \\
\hline Cafeteria & $15(4.0)$ \\
\hline Bathrootn & $28(8.1)$ \\
\hline On the way home from schod & $55(15.3)$ \\
\hline \multicolumn{2}{|l|}{ Time of bullying behavior } \\
\hline During study hours & $117(33.4)$ \\
\hline At change of academic subject & $32(9.0)$ \\
\hline During shool recess & $152(43.4)$ \\
\hline On way home from school & $49(14.2)$ \\
\hline \multicolumn{2}{|l|}{ Reporting $f$ bull ying behavior } \\
\hline Friends & $79(24.1)$ \\
\hline Older/younger brothers & $42(12.8)$ \\
\hline Parents & $40(12.2)$ \\
\hline Teachers & $21(6.4)$ \\
\hline No reporting & $146(44.5)$ \\
\hline
\end{tabular}

physical bullying (24.7\%) and cyber bullying (7.8\%) (Table 1). The subjects who were involved as victim and bully-victim stated that most of the bullies were classmates (58.5\%), bullying behavior occurred more frequently in the classroom (37.2\%) and during school recess (43.4\%). A total of $24.1 \%$ victims and bullyvictims reported the occurrence of bullying to their friends, $12.8 \%$ reported to their older or younger siblings, $12.2 \%$ to their parents and $6.4 \%$ to their teachers (Table 1).

The results of simple logistic regression analysis showed that the variables of self-esteem, type of family relation, and parenting pattern were significantly associated with bullying role $(p<0.050)$. Evaluation of the results of the Rosenberg Self-Esteem Questionnaire indicated that $67.9 \%$ of subjects with low self-esteem were involved in bullying i.e. $38.3 \%$ as victims, $11.1 \%$ as bullies and $18.5 \%$ as bully-victims. On the other hand, subjects with low self-esteem who were not involved in bullying accounted for $32.1 \%$. Simple logistic regression showed that the proportion of self-esteem was significantly different between subjects who were involved and those who were not involved in bullying (victims $\mathrm{p}=0.011$; bullies $\mathrm{p}=0.021$; bully-victims $\mathrm{p}=0.012$ ). Depression in subjects who were involved in bullying was higher (54.7\%) than in subjects who were not involved in bullying (45.3\%). Subjects with depression who were involved in bullying were encountered in the groups of victims $(22.5 \%)$, bullies $(16.3 \%)$ and bully-victims (15.9\%). Depression was not a risk factor of bullying behavior (victims $\mathrm{p}=0.664$; bullies $\mathrm{p}=0.583$; bully-victims $\mathrm{p}=0.783$ ) (Table 2).

Evaluation of the total score for the Strength and Difficulties Questionnaire (SDQ) indicated that $47.5 \%$ of subjects involved in bullying had emotional and behavioral problems, of which $18.1 \%$ as bullies, $17.6 \%$ as victims and $12.1 \%$ as bully-victims. Simple logistic regression showed that emotion and behavior did not constitute a risk for bullying behavior (victims $\mathrm{p}=0.293$; bullies $\mathrm{p}=0.272$; bully-victims $\mathrm{p}=0.274$ ). 
Table 2. Relationship of psychological and family factors with bullying behavior

\begin{tabular}{|c|c|c|c|c|c|c|c|c|c|c|c|c|}
\hline \multirow{3}{*}{ Varialle } & \multicolumn{12}{|c|}{ Oddsrati derninans of bulyinghehaior } \\
\hline & \multirow{2}{*}{$\begin{array}{l}\text { Uniwoke } \\
\text { d (IF } 728)\end{array}$} & \multicolumn{4}{|c|}{ Vetins (IF 346) } & \multicolumn{4}{|c|}{ Bulles (IF TT) } & \multicolumn{3}{|c|}{ Brly-Wetins (n= $=\Gamma 3)$} \\
\hline & & n(\%) & $\mathbf{p}$ & Exp & $95 \% \mathrm{CI}$ & $\mathbf{n}(\%)$ & $\mathbf{p}$ & $\mathbf{E x p}$ & $95 \% \mathrm{C}$ & $\mathbf{n}(\%)$ & $\mathbf{p} \quad \mathbf{E x p}$ & $95 \% \mathrm{C}$ \\
\hline \multicolumn{13}{|l|}{ Selfeterem } \\
\hline High & $573(6720$ & $36(4.2)$ & \multirow{2}{*}{$0001 *$} & \multirow{2}{*}{20.4} & \multirow{2}{*}{81.492 .7} & $147(172)$ & \multirow{2}{*}{\multicolumn{3}{|c|}{$0.021 * 16.7432-568$}} & $97(11.4)$ & \multirow{2}{*}{$0012 * 183$} & \multirow{2}{*}{11.9459} \\
\hline Law & $155(32.1 \%$ & $185(383)$ & & & & $\Phi(11.1)$ & & & & $8(185)$ & & \\
\hline \multicolumn{13}{|l|}{ Depesion } \\
\hline Plesent & $109(4532)$ & $58(225)$ & 0664 & 36 & $718-1233$ & $42(163)$ & 0583 & 36 & $223-398$ & $49(159)$ & 07832.4 & $390-788$ \\
\hline Absent & $619(583 \%$ & $111(10.4)$ & & & & $12(161)$ & & & & $162(152)$ & & \\
\hline \multicolumn{13}{|l|}{$\begin{array}{l}\text { Beleviaral } \\
\text { and encotianal }\end{array}$} \\
\hline $\begin{array}{l}\text { poblems } \\
\text { Foritive }\end{array}$ & $294(522 \%$ & $99(176)$ & 0293 & 3.7 & $34.1-562$ & $100(181)$ & 0272 & 48 & $520-238$ & $68(121)$ & 027432 & $781-985$ \\
\hline Negative & $499(602 / 0$ & $97(118)$ & & & & $122(161)$ & & & & $\Phi(119)$ & & \\
\hline \multicolumn{13}{|l|}{$\begin{array}{l}\text { Type of firvily } \\
\text { pelation }\end{array}$} \\
\hline Balarced & $252(57.4 \%$ & $66(146)$ & $0,0,2 *$ & 6.4 & $37.1-59.1$ & $71(157)$ & $0,020 *$ & 58 & $429-675$ & $\$(113)$ & $0,031 * 49$ & 229.428 \\
\hline Midrange & $400(62.1 \%$ & $97(158)$ & & & & $6(118)$ & & & & $66(103)$ & & \\
\hline Extreme & $233(5830)$ & $71(175)$ & & & & $\Phi(131)$ & & & & $44(11.1)$ & & \\
\hline Parertirg pattern & & & $0,000^{*}$ & 363 & 21233.56 & & $0011 *$ & 278 & $122-229$ & & $0010 * 316$ & $298-655$ \\
\hline Exposire & $576(69320$ & $83(990)$ & & & & $97(117)$ & & & & $6(9.1)$ & & \\
\hline NanExposure & $152(309 / 0)$ & $100(209)$ & & & & $124(253)$ & & & & $113(229)$ & & \\
\hline
\end{tabular}

Note: $\mathrm{CI}=$ Confidence Interval to Mean $95 \%$; $\mathrm{p}^{*}=$ Significant association

The majority $(56.6 \%)$ of study subjects had a midrange type of family relation (adequate cohesion and adaptation), while $41.4 \%$ of subjects involved in bullying had an extreme type of family relation (low cohesion and adaptation), with $17.1 \%$ victims, $10.8 \%$ bullies, and $13.55 \%$ bullyvictims. Simple logistic regression showed that the proportion of the extreme type of family relation was significantly different between the subjects who were involved and those who were not involved in bullying (victims $\mathrm{p}=0.022$; bullies $\mathrm{p}=0.020$; bully-victims $\mathrm{p}=0.031$ ). The majority of subjects who were involved in bullying $(57.1 \%)$ had a non-exposure pattern of parenting (unexpected, inconsistent, permissive, overprotective), while of those who were not involved in bullying, there were more $(79.1 \%)$ who had an exposure parenting pattern (expected, democratic). Simple logistic regression showed that the proportion of non-exposure parenting was significantly different between subjects who were involved and those who were not involved in bullying (victims $\mathrm{p}=0.020$; bullies $\mathrm{p}=0.011$; bullyvictims $\mathrm{p}=0.010)$.

Simple logistic regression found three variables with $\mathrm{p}<0.25$, i.e. self-esteem, family relation, and parenting pattern, that played a role in the occurrence of bullying behavior. These three variables were further analyzed using multiple logistic regression. The results of the latter analysis showed that there were two variables affecting bullying behavior, i.e. selfesteem and parenting pattern. The variable of self-esteem had an odds ratio of 23.89 (95\%

Tabel 3. Factors with a role in the occurrence of bullying behavior

\begin{tabular}{lcccc}
\hline \multirow{2}{*}{ Variab le } & \multirow{2}{*}{ P } & \multirow{2}{*}{ Exp (B) } & \multicolumn{2}{c}{ 95\%CI for EXP(B) } \\
\cline { 4 - 5 } & & & Lower & Upper \\
\hline Fam ily relation & 0.085 & 1.79 & 0.925 & 3.422 \\
N on-expcoure parting & 0.000 & 39.11 & 2.455 & 8.210 \\
Self-esteem & 0.004 & 23.89 & 7.899 & 12.990 \\
\hline
\end{tabular}


CI:7.899-12.990), signifying that subjects with low self-esteem had a 23.89 times greater probability of being involved in bullying behavior, as compared with subjects with high self-esteem. The variable of parenting pattern had an odds ratio of 39.11 (95\% CI: 2.455 8.210 ), signifying that subjects with the nonexposure type of parenting (permissive, authoritarian, inconsistent) had a 39.11 times greater probability of being involved in bullying behavior, as compared with the exposure type of parenting (democratic).

\section{DISCUSSION}

The prevalence of bullying in this study was found to be $45.1 \%$, with $53.5 \%$ females and $41.4 \%$ males. Females were more involved as victims of bullying (20.3\%), while males were more involved in bullying as perpetrators (23.5\%). Bullying behavior is a worldwide health problem and its prevalence is increasing from year to year. ${ }^{(1)}$ Flemming et al. ${ }^{(12)}$ stated that the prevalence of bullying in Asia, America and Europe was estimated to be $40-80 \%$. The incidence rate of bullying in the present study was essentially similar to that of the study by Flemming. Data from the National Mental Health and Education Center in the US indicate that bullying is a form of violence that generally occurs in the school environment, where $15 \%$ of students are the perpetrators of bullying and 30\% of students are the victims of bullying. ${ }^{(13)}$

The frequently encountered type of bullying in this study was the verbal type, followed by psychological and emotional, physical, and cyber bullying. The verbal, psychological and emotional types of bullying and cyber bullying were more frequently experienced by female than male subjects. On the other hand, the physical type of bullying was more frequently experienced by male than by female subjects. The most frequently found form of bullying in schools were taunting, gossiping or rumor-spreading, followed by hitting and threatening. ${ }^{(12,13)}$ The study of Stein et al. ${ }^{(14)}$ showed that the most frequent type of bullying was the verbal type (taunting, name calling), followed by psychological and emotional bullying (spreading of rumors, social isolation), physical bullying (threatening, hitting), and cyber bullying.

The results of this study found that bullying occurred more frequently in the classroom. This finding is in agreement with the study by Nordhagen et al. ${ }^{(15)}$ where the classroom, when the teacher was absent, was most frequently used as the location of bullying behavior. Interactions between students were most frequent in the playgrounds, hallways, and classrooms, so that bullying was frequently experienced by the victims in those locations. Bullying may occur anywhere, particularly in locations with minimal supervision by teachers and school personnel, due to the high teacher-student ratio. This study showed that only around $55.5 \%$ of victims and bully-victims reported the bullying episodes that they had experienced to their friends and family members (parents, siblings) and that only $6.4 \%$ of both victims and bully-victims reported to their teachers. The unwillingness of the students to report the bullying that they experienced to their teachers may be caused by the lack of confidence of the students in their teachers. Incorrect perception, attitude, and acts of teachers towards bullying behavior may result in the low confidence of students in the educational institution and encourage bullying behavior in schools. Actually the ability of teachers to encourage student confidence and remove the gap between teachers and students constitutes the foundation for fighting bullying in schools. ${ }^{(15,16)}$ Low self-esteem was most frequently found among subjects who were involved in bullying (67.9\%) compared with those who were not involved in bullying (32.1\%). Subjects with low self-esteem who were involved in bullying were most numerous among the victims and bullyvictims. The victim of bullying is a weak person without peer group support. The majority of victims had low self-esteem and were taciturn and shy. Our study results agree with those of the study by Spade ${ }^{(17)}$ who also used the 
Rosenberg Self-Esteem Questionnaire, stating that adolescents who were involved in bullying behavior, both as victims and bully-victims, had a significant correlation with low self-esteem. Spade also stated that adolescents with low selfesteem were at risk both as victims and bullyvictims.

In this study the prevalence of depression was most frequently found among victims $(22.5 \%)$, followed by bullies (16.3\%) and bullyvictims (15.9\%). The incidence rate of depression in this study among subjects who were involved in bullying differed with those of the study of Kaltiala-Heino et al. ${ }^{(18)}$ who stated that the prevalence of depression was higher in the bullyvictims (44\% females and $23 \%$ males) than in the victims (26\% females and $16 \%$ males). Depression may be one of the psychological impacts of bullying behavior or an influential risk factor for the occurrence of bullying behavior. Our study did not perform initial screening for depression as impact or risk factor of bullying behavior. This study also showed that the proportion of emotional and behavioral problems among subjects who were involved in bullying as perpetrators (bullies) was $18.1 \%$, as victims $17.6 \%$ and as bully-victims $12.1 \%$. Our study results differed with those of the study by Gini ${ }^{(19)}$ who also used the SDQ instrument and found that the proportion of emotional and behavioral problems among subjects involved in bullying as victims was $19.2 \%$, as bullies $14.3 \%$, and as bully-victims $27.1 \%$.

Victims of bullying and bully-victims were at higher risk for experiencing mental- emotional problems than were the perpetrators. ${ }^{(18)}$ Victims and bully-victims frequently showed symptoms such as anxiety, depression, always feeling insecure, being extremely cautious, having low self-esteem and tending to have limited social interaction and to be isolated by their peers. Perpetrators of bullying behavior more frequently showed behavioral problems and abnormalities such as aggressive behavior, impulsivenes, lack of empathy, challenging and destructive attitude. ${ }^{(19,20)}$
Around $17.1 \%$ of subjects who were involved in bullying had extreme family relations (rigid family relation, low emotional bonding). Victims were most frequently found to have extreme family relations. In families with rigid and poor family relations, lack of communication, lack of emotional bonding (closeness) and lack of harmony between family members, the adolescent members may lack guidance and care in their moral and emotional development, so that they grow up with negative perceptions and views towards themselves and their environment, and are at risk of mental emotional problems (depression, anxiety, bipolarity) and behavioral problems (conduct disorder, bullying). ${ }^{21)}$ The non-exposure type of parenting pattern (unexpected, inconsistent, overprotective or overindulgent) were more frequently found in subjects who were involved in bullying (57.1\%). Achenbach and Edelbrock (22) stated that overindulgent, too rigid and harsh (authoritarian) or inconsistent parenting in disciplining, influenced the personality formation of adolescents, who will be at high risk of mentalemotional problems (depression, anxiety, bipolarity) and behavioral problems (conduct disorder, bullying).

Our study showed that the non-exposure type of parenting pattern constituted the strongest risk factor for bullying behavior among adolescents. This is in accordance with the study of BacikovaSleskova et al. ${ }^{(23)}$ who found a significant association between parenting pattern and bullying behavior. Their study also stated that the role of parents was essential to instill good behavior and emotions in their adolescent children. Permissive and inconsistent (nonexposure) parenting is the nurturing pattern of parents who give too much freedom to their adolescent children without adequate supervision and tends to form adolescents who are agressive, impulsive, and egoistic. In contrast, children with authoritarian parenting may acquire a too rigid character, become headstrong and easily anxious and depressed. Parenting pattern and the role of parents as good 
educators (exposure, democratic) can prevent the occurrence of behavioral and emotional problems, mental-emotional disorders and bullying behavior. Parents are expexted to be capable of giving basic counseling and guidance about morals and religion, and build effective communication with their adolescent children. ${ }^{(22,23)}$

Self-esteem is a risk factor of bullying behavior. Adolescents with low self-esteem tended to be 23.89 times more involved in bullying as compared with adolescents with high self-esteem. Tritt and Duncan ${ }^{(24)}$ stated that adolescents with low self-esteem tended to be 18.90 times more involved in bullying than those with high selfesteem. Adolescents with low self-esteem were at risk for the occurrence of mental-emotional health problems, substance abuse and addiction, and bullying behavior. Salmon ${ }^{(25)}$ stated that students who had been involved in bullying, either as bullies, victims or bully-victims, had a significant correlation with low self-esteem; the worst bullying behavior was associated with the lowest self-esteem.

A limitation of this study lies in its crosssectional design, so that it cannot explain any causal relationship among junior high school students between parenting pattern and self-esteem on the one hand and bullying behavior on the other. Further studies should be conducted using a longitudinal study design, to be able to explain any such causal relationship. This study was carried out among junior high school students, so that our study results are not representative of bullying behavior in adolescents outside the school environment. These study results are expected to lead to comprehensive management of adolescents who are involved in bullying behavior at school, i.e. both the physical and psychological aspects, by involving the family (particularly the parents) and school teachers.

\section{CONCLUSIONS}

Non-exposure parenting is the largest risk factor of bullying behavior. Low self-esteem increases the risk of mental-emotional disturbances (depression, anxiety), conduct disorder, and bullying behavior .

\section{CONFLICT OF INTEREST}

There are no conflicts of interest.

\section{ACKNOWLEDGMENT}

We thank all students of grades I, II, and III of state junior high school 23 (SMP Negeri 21) and of the private junior high schools (Pluit Raya, Genesareth, Wijaya Kusuma) in Kelurahan Penjaringan who agreed to become respondents in this study. We also thank the heads and teachers of the schools, who permitted this study and helped in the course of this study.

\section{REFERENCES}

1. Novianti I. Fenomena kekerasan di lingkungan pendidikan. J Insania 2010;13:1-10.

2. Harris S. Bullying at school among older adolescents. School Nurs Rev 2010;22:18-21.

3. Nation M, Vieno A, Perkins D. Bullying in school and adolescent sense of empowerment: an analysis of relationship with parents, friends, and teachers. J Community Applied Soc Psychol 2011;10:115-27.

4. Wang J, Iannotti RJ, Nansel TR. School bullying among adolescents in the United States: physical, verbal, relational, and cyber. J Adolesc Health 2009;45:368-75.

5. Olweus D. Bullying at school: basic fact and effect of a school based intervention program. $\mathbf{J}$ Child Psychol Psychiatry 2009;35:171-90.

6. Cook C, Williams KR, Guerra NG, et al. Predictors of bullying and victimization in childhood and adolescence: a meta-analytic investigation. Sch Psychol 2010;25:65-8

7. Nurhamzah W, Maureen A, Wiguna T. Gambaran bullying dan hubungannya dengan masalah emosi dan perilaku pada anak Sekolah Dasar. Sari Pediatri 2013;15:174-80.

8. Weir E. The health impact of bullying. Can Med Assoc J 2011;1:1245-9.

9. Arseneault L, Bowes L, Shakoor S. Bullying victimization in youths and mental health problems: 'much ado about nothing'? Psychol Med 2010;40:717-29. 
10. Van der Wal MF, de Wit CAM, Hirasing RA. Psychosocial health among young victims and offenders of direct and indirect bullying. Pediatrics 2003;111:1312-7.

11. Brixval CS, Rayce SL, Rasmussen M. Overweight, body image and bullying-an epidemiological study of 11-15 years olds. Eur J Public Health 2011;3:123-5.

12. Flemming LC, Jacobsen KH. Bullying among middle school students in low and middle income countries. J Health Promotion 2010;25:73-82.

13. Nansel TR, Overpeck M, Pilla RS, et al. Bullying behaviors among U.S. youth: prevalence and association with psychosocial adjustment. JAMA 2001;285:2094-100.

14. Stein JA, Dukes RL, Warren JI. Adolescent male bullies, victims, and bully-victims: a comparison of psychosocial and behavioral characteristics. J Pediatric Psychol 2007; 32:273-82.

15. Nordhagen R, Nielsen A, Stigum H, et al. Parental reported bullying among Nordic children: a population-based study. Child Care Health Dev 2009;31:693-701.

16. Smokowski, Kopasz. Bullying in school: an overview of types, effects, family characteristics, and intervention strategies. J Pediatric Psychol 2010;27:101-9.

17. Spade JA. The relationship between student bullying behaviours and self-esteem [dissertation]. New York: College of Bowling Green State University;2010.
18. Kaltiala-Heino R, Rimpela M, Marttunen M, et al. Bullying, depression, and suicidal ideation in Finnish adolescents: school survey. BMJ 2011;3:348-51.

19. Gini G. Association between bullying behaviour, psychosomatic complaints, emotional and behavioural problems. J Paed Chlid Health 2011; 44:492-7.

20. Garner PW, Hinton ST. Emotional display rules and emotional self-regulation: associations with bullying and victimization in community-based after school programs. J Community Appl Psychol 2010;20:480-9.

21. Holt MK, Espelage DL. Perceived social support among bullies, victims, and bully-victims. J Youth Adolesc 2007;36:984-9.

22. Achenbach TM, Edelbrock CS. Behavioral problems and competencies reported by parents of normal and disturbed children aged four through sixteen. Monogr Soc Res Child Dev 2010;2:123-9.

23. Bacikova-Sleskova M, Madarasova GA, van Dijk JP, et al. Parental support and adolescents' health in the context of parental employment status. J Adolesc 2011;34:141-9.

24. Tritt C, Duncan RD. The relationship between childhood bullying and young adult self-esteem and loneliness. J Humanistic Educ Develop 2009;36:35-44.

25. Salmon G. Bullying in school: self-reported anxiety and self-esteem in secondary school children. BMJ 2008;3:924-5. 